vinced that it was of so great importance as some thought, to retain a large number of very old servants in an usylum. If they were to have such a large number as twenty ont of thirty-seven, who had boen from ten to twenty years in the asylum, they knew that they gradually had a very extensive power over which the superintendents had practically no control whatever. For these reasons he was convinced that any such system as a systematic arrangement of pensions for asylum services would be highly objectionable. The thing to induce servants to go to an asplum was to give good present pay.

Dr. Howden said that his mind was by no means decided on the question. He thought there was a good deal of truth in what Dr. Take had said. There was a difference between the case of warders in a prison and attendants in an asylum. He held that the superintendents ought to have complete control over attendants in engaging and dismissing them. There was a great risk, if they made the plan on the same footing as that of prison warders, that they would be saddled with inefficient servants. He thought a great deal of the difficulty might be got over by giving the attendants high wages, and let them pension themselres, as most men and women did who were saving. At the same time, if it would have the effect of getting a better class of people, and getting them to remain, it would be a great advantage to have pensions both for officers and attendants. He thought that they should know something of the experience of their English brethren on the subject before deciding the matter. Was it a fact or not that they got better attendants in England than in Scotland P He thought that the changes in the English agylums were very frequent if he could judge from the advertisements in the Sootsman.

Dr. RUThER FORD said that the question was whether the privilege ought to be withheld from the district asylums. The object was to place the district asylums on the same footing as the chartered asylums, and to give the district boards the power of granting pensions.

The Chairman said it seemed reasonable that their district asylum brethren should be placed on the same footing as those belonging to the chartered asylums. He agreed with that, but as to getting up a petition for the pensioning of officers and other servants, he was not prepared to approve of such a pro. ceeding. Dr. Tuke had expressed his (the chairman's) own view of the matter. He did not think that they should have anything to do with the getting of retiring allowances for the servants. It was important that they should engage the servants, and be able to dismiss them. If the proposed alteration was made it would come to this that a committee would hire their servants, whom they would not be at liberty to dismiss without the consent of the General Lunacy Board. He thought it was important that they should have their servants under their own authority; and it would introduce a distarbing element if they were to lead these people to suppose that they had other masters. He did not believe that he could get very much better servants than he had at present. He gave the wages of the district, and more when he found it was necessary. He thought that a committee should be appointed to deal with the matter, and report to a future meeting of superintendents of asylums.

This was agreed to, and after votes of thanks to the Chairman, and to the Boyal Society for the use of their rooms, the meeting separated.

\title{
THE LATE THOMAS LAYCOCK, M.D.
}

By the death of Prorrssor Laycock, the Association-of which this Journal is the literary organ - has lost one of its most distinguished members and brightest ornaments. In electing him to the office of President in 1869, and enrolling his name in the list of its Honorary Members, the Association gave expression to the high estimation in which it held him. And no one upon whom these honoure have been conferred, took a deeper intereat and contributed 
more zealously in promoting the highest aims of the Association. He will always be remembered an ampnr the most eminant, of. those who have helped to raise the study of mediorne to the dignity of a science; and his work in demonstrating the interdependence of physiology, pathology, and psychology, will constitute his chief claim to this honourable position. The following extract from the "British Medical Journal" of September 30th is an appreciative notice of his life and work :-

"On September 21st, there passed away in Edinburgh one of the most voluminous writers, ingenions thinkers, and hardest workers in our profession. Dr. Laycock, the eradite Professor of the Practice of Medicine in the University, died of pulmonary consumption at his house in Walker Street, Edinbargh on that day. He had been unable to attend to his professional duties for about five months, his disease being a fresh ontbreak of phthisis, with which he had been threatened twenty years previously. At that time his life was prononnced to be a most precarions one by several of the best men in London, but he seemed to have quite recovered. In 1866, he had his left leg amputated by Mr. Spence for disease of the knee joint, and, for a time, his life was in the ntmost danger, while his sufferings were most intense. Ever since then he has been somewhat of an invalid, but active and hard-working as ever. In April last he caught cold on a railway journey; the old mischief in his right lung seemed to have been roused into fresh action; he begun to cough, and to suffer from dyspnce and romiting after meals, and those symptoms steadily increased in spite of treatment. His strength was utterly prostrated at the last, but mentally he was quite clear, and as fond as ever of speculating about his own symptoms and sensations and his favourite medical questions. The post mortem examination showed old disease of both lungs, with a considerable amount of recent tubercular degeneration all through the right. The brain showed some atrophy, the convolutions were exceedingly numerons, and it weighed fortyeight ounces. He was sixty-four years of age.

" Dr. Laycock was the son of a Wesleyan minister, and was born on Augast 10th, 1812, at Witherby in Yorkshire. At fifteen, he was apprenticed to Mr. Spence, surgeon, of Bedale. He afterwards studied at University College London, and then, in 1833, went to study in Paris under Louis, Velpean, and Lisfranc at La Pitié. After his return, he was appointed Resident Medical Officer of the York County Hospital; and, in 1839, he took his M.D., sumina cum laude, at Göttingen. He was appointed Physician to the York Dispensary in 1841, Statistical Secretary to the British Aseociation in 1844, Lecturer on the Theory and Practice of Medicine at the York School of Medicine in 1846, and, in 1855, he attained the crowning point of his professional life, by being elected Professor of the Practice of Medicine and Clinical Medicine in the University of Edinburgh, succeeding Dr. Alison in the Chair of Cullen. He taught there and practised as a consulting physician up to his death, with the exception of the session 1866.67, while he was suffering from the knee-joint disease and the effects of the amputation, when the late Dr. Warbarton Begbie lectured for him in the Practice of Physic Course, and Dr. W. A. F. Browne in Medical Psychology; and the summer session of 1876, when Dr. Clouston, who had, since 1873, been associated with him in the latter course, and in the cliniques at the Royal Edinburgh Asylum, took his place with the assistance of Dr. Murdoch Brown. He was an F.R.C.P.E. and F.R.S.E., and Physician to Her Majesty for Scotland. He was chiefly consulted for nervous diseases, but his practice was never extensive in Edinburgh.

“ Dr. Laycock began to contribute to medical literature at a very early period of his professional life, and continued to do so unceasingly erer since. Anything like the list of all the papers and works he wrote could not possibly come in time. It is sufficient to say that they numbered over three hundred; and are to be found in almost every medical journal and periodical published in this country. His first paper was On the Acid and Alkaline Reaction of the Saliva,

XXII. 
published in the London Medical Gazette, in 1837; and his last was On Reflex Antomatic and Unconscions Cerebration, in the Journal of Mental Science for Jannary and April, 1876. He translated Prochaska's Nervous System, and Unzer's Principles of Physiolngy. He published his Nervous Diseases of Women in 1840; his Principles and Methods of Medical Obsernation and Research in 1856; and his Mind and Brain in 1860. Many of these went through more than one edition, and each new edition always contained much new matter-in fact, was generally re-written throughout.

"On considering this work of a man who has contributed so much to medical literature, the questions that naturally arise are: What has he done for medical science? What discoveries will be associated with his name ? What generalisations has he made? We think that those questions can be answered in Laycock's case very satisfactorily now; and that, a hundred years hence they will still be capable of being answered to his lasting fame. We shall place his work in what we think the order of its importance. The doctrine of the reflez functions of the brain, which he was the first to formulate in 1844 (British and Foreign Medical Review, January, 1845), has slowly but steadily acquired a strength of belief that now places it among the accepted laws of brain-physiology. It threw a flood of light on many obscure points-and all points were then obscure-in brain and mind function and disease. It has been extended by Carpenter, and admits of still further extension. His next most important work, we think, may be reckoned to be the series of facts, generalisations, and speculations, contained in his work on Mind and Brain, in regard to the connection of mental power and deficiency, erolution and decay, peculiarity and disease, with the molecular changes in the encephalon and with states of brain. No one can say that his attempt to correlate conscionsness and organisation, in all their myriad phases, was a completely successful one, but few physicians will now deny that Laycock's point of view is the true one that his whole governing idea is that of the genuine medical philosopher; and that the very attempt was a noble and masterly one. The mere labour of collecting and arranging the facts was gigantic; and we believe that, if his lucidity had been equal to his depths, and his power of exposition equal to his thinking, his book would have marked an epoch alike in physiology and in psychology. It will ever remain a landmark in the region of the contact of mind with organised living matter. His work on Hysteria and Ubscure Nervous Diseases will, we think, stand the test of time. It brought some order ont of absolute chaos. His observations and hypotheses as to the effect of the brain and nerve-centres in the causation and regulation of animal temperature in health and disease, of nutrition, of anasarcas, of rheumatic and gouty inflam. mations, and in diseases generally, were both highly original and practical. He did much to make trophic centres in the brain real to medical men. His theories of diatheris and their applications to disease were most original, and brought into notice facts of importance to the practitioner. His theory of limited 'vascular areas' in the brain corresponding to certain functional areas, and of the general correspondence between this development in embryo of the great nerve-centres and the great vascular tracts in the brain, bave received much confirmation from the investigations of Heubner and Duret. His theory as to the division of the brain into the three systems of the basilar correspond. ing to animal life, the middle to sensorial-animal, and the higher to the intellectual and inhibitory functions of man, no doubt, contains much truth. His theory of the functions of the cerebellnm being that of storing up and giving out, in a regulated way, supplies of vis nervosa, is highly ingenions. He was one of the first to apply the doctrine of evolution to the development of the nervous centres in the animal kingdom and in man; and, indeed, in one of his early papers he foreshadowed the evolution theory. His speculations as to 'organic memory,' and its hereditary transmission, are well worthy of study. And the last, but not least, of his achievements which the space at our disposal will allow us to mention, are his labours and writings in regard to publio 
health. His papers on the Development of a General Law of Vital Periodi. city and of the Return of Epidemics, on the Vital Statistics of England, and the Public Hygiene of Great Britain, and his Report of the Sanitary Condition of York, were of the greatest importance to the science of hygiene at a time when it was struggling and unheeded. They clearly showed that Laycock was no mere theorist. Looking at Dr. Laycock from a psychological point of view, he was a man of immense and unceasing industry, both in reading and thinking, of wide grasp, and of great mental ingenuity. His was a speculative and philosophical mind, with a strong tendenoy to look into the reasons of things, to think about everything, and to generalise in regard to everything he thought about. This was, in other respects, his weak point, for he could not help coming to general laws in regard to his facts, whether they admitted them or not. In his lectures on fever, he had every pyrexia to which a name had ever been given all marshalled in genera, and species, and groups, just like a botanist with his plants. He was systematic and orderly in his work, in his reading, and in his storing up of facts, of which he was a close observer and collector. The daily newspapers contained for him many facts illustrating medical psyohology, which were duly cut out and put in their proper places. The medical press always contained cases illustrating his theories or suggesting others. His cases in hospital were always suggesting new ideas, and, above all, his reading of medical books-and we believe he was the best read man in English, German, and French medical literature in his profession-was ever bringing new ideas, and adding to his facts.

"As a teacher, we must admit that Laycock did not always reach or interest the average medical student. He was, however, highly suggestive to the more thoughtful in his classes, and his teaching influenced them permanently throughout their lives, often giving a direction to their studies. He did very much for the teaching of mental diseases in the University of Edinburgh. He originated a summer conrse of lectures on 'Medical Psychology and Mental Diseases,' and had often as many as forty students. Many men took to asylum life in this way. His class was the nest from which many of the Northern Asylum superintendents took their fledgling assistants.

"Personally, he was a man rather under the middle size, with a beautifully shaped head and very well cut features, of the 'Neuro-arthritic diathesis,' as he described himself, with rather a cold manner, giving the impression of being somewhat egotistical, and not sufficiently alive to the feelings and anrour propre of others. But, to those who knew him better, he was a genial com. panion and friend. He was a widower since 1869, and leaves a son and daughter; the former, Mr. G. L. Lascock, took his M.B. degree in the University of Edinburgh in August last."

\section{THE RELATION OF DRINK AND INSANITY.-LETTER BY DR. PEDDIE.}

To the Editors of The Journal of Mentax Scinnce.

Sirs.-When I pat my letter of 21st July into your hands for publication in the October Number of the Journul, I gave you in writing a most cordial permission to send a proof of it to Dr. Backnill in ample time for a reply in the same Number if he chose to make it. If, therefore, there was any blunder. ing of the printer afterwards, the responsibility did not rest with me; but even supposing it had been otherwise, I think there can be but one feeling with your readers, that the whole strain of Dr. Bucknill's letter in reply displays an animus and intemperate zeal unaccountable considering the nature of the question under discussion, and uncalled for by any remarks made by myself on his Rugby speech and letter to one of yourselves. Indeed, this remarkable production is written in a tone which to me at least is unexpected, as coming 